\title{
How to overcome osmotic stress? Marine crabs conquer freshwater. New insights from modern electrophysiology*
}

\author{
H. Onken ${ }^{1}$, K. Graszynski ${ }^{1}$, A. Johannsen ${ }^{1}$, M. Putzenlechner ${ }^{1}$, \\ S. Riestenpatt ${ }^{2}$, C. Schirmer ${ }^{1}$, D. Siebers ${ }^{2} \&$ W. Zeiske ${ }^{1}$ \\ ${ }^{1}$ Institut für Tierphysiologie, FU Berlin; Grunewaldstr. 34, D-12165 Berlin, Germany \\ ${ }^{2}$ Biologische Anstalt Helgoland, Zentrale Hamburg; Notkestr. 31, D-22607 Hamburg, \\ Germany
}

\begin{abstract}
In the present article we review our findings on split lamella preparations of crab gills mounted in modified Ussing-chambers with respect to mechanistic and ecophysiological aspects. The leaky gill epithelium of shore crabs adapted to brackish water absorbs $\mathrm{Na}^{+}$and $\mathrm{Cl}^{-}$in a coupled mode, and shows similarities to other salt-absorbing epithelia exposed to moderately diluted media. The results so far obtained for $\mathrm{NaCl}$ uptake across the gills of the shore crab are compatible with a transport model where two cell types operate in parallel, one displaying cotransport-like $\mathrm{NaCl}$ absorption, similar to that in the thick ascending limb of Henle's loop of the mammalian mephron, and the other one with characteristics of amiloride-sensitive, channel-mediated $\mathrm{Na}^{+}$uptake by frog skin. Although there is no clear evidence for the apical mechanisms in this model, it may serve as a good basis for more detailed studies in the future. The moderately tight gill epithelium of freshwater adapted Chinese crabs absorbs $\mathrm{Na}^{+}$and $\mathrm{Cl}^{-}$independently from each other, and shows similarities to other salt-absorbing epithelia exposed to freshwater. The characteristics of a positive, $\mathrm{Na}^{+}$dependent short-circuit current with externally $\mathrm{Cl}^{-}$-free saline indicate that active $\mathrm{Na}^{+}$uptake proceeds in a frog-skin-like mode via apical $\mathrm{Na}^{+}$-channels and the basolateral $\mathrm{Na}^{+} / \mathrm{K}^{+}$-pump. The nature of a negative short-circuit current with external $\mathrm{Cl}^{-}$-saline indicates that active and $\mathrm{Na}^{+}$independent $\mathrm{Cl}^{-}$uptake is driven by an apical $\mathrm{V}$-type $\mathrm{H}^{+}$-pump and proceeds via apical $\mathrm{Cl}^{-} /$ $\mathrm{HCO}_{3}{ }^{-}$-exchange and basolateral $\mathrm{Cl}^{-}$-channels.
\end{abstract}

\section{INTRODUCTION}

Most crustacea of the group Brachyura, commonly known as crabs, live in seawater. In this medium they are not confronted with serious osmotic problems. Their haemolymph is nearly iso-osmotic with respect to seawater. However, many crab species migrate to brackish water, and a few groups even conquer freshwater. In these diluted

\footnotetext{
- This paper is a summary of three articles presented at the Symposium commemorating the Centenary of the Biologische Anstalt Helgoland (13th-18th September, 1992): (1) "How to overcome osmotic stress? Marine crabs conquer freshwater" (Graszynski et al.); (2) Poster: "Na ${ }^{+}$. and $\mathrm{Cl}^{-}$-uptake across posterior gills of Eriocheir sinensis acclimated to freshwater" (Graszynski et al.); (3) "Electrogenic uptake of $\mathrm{NaCl}$ across split lamellae of posterior gills of low-salt adapted shore crabs (Carcinus maenas)" (Onken \& Siebers).
} 
media they need mechanisms to hyperregulate the osmotic concentration of their body fluids.

In this short review, we focus on recent advances in the understanding of absorptive, electrogenic ion movements across posterior crab gill, the major tissue for salt balance during osmoregulation of these animals (for extensive reviews see: Mantel \& Farmer, 1983; Graszynski \& Bigalke, 1987; Siebers et al., 1987; Pequeux et al., 1988; Lucu, 1990). This has become possible in the last few years by the application of modern electrophysiological techniques to isolated epithelial layers which were mounted in an Ussingchamber (Schwarz \& Graszynski, 1989; Onken, 1989; Schwarz, 1990; Onken et al., 1991; Zeiske et al., 1992; Onken \& Siebers, 1992).

\section{THE SPECIAL OSMOTIC PROBLEM OF CRABS}

All animals which live in diluted media are confronted with an essential problem: the passive influx of water and efflux of salt across permeable body surfaces, threatening to increase the volume of their body fluid and to decrease its osmotic concentration. In freshwater animals, like amphibians, fish and crayfish, t wo epithelia function together to overcome these problems: (a) a special segment of their nephridial system actively reabsorbs ions, facilitating the production of hypo-osmotic urine, and (b) body surface epithelia (skin, gills) actively absorb salts from the diluted external medium, which compensates for losses.

In contrast, all crabs produce iso-osmotic urine, because they lack mechanisms for an effective ion reabsorption in their nephridial system, the antennal gland (Mantel \& Farmer, 1983). Thus, in diluted external media, they suffer from an additional ion leak in their haemolymph system. Moreover: being originally marine animals, crabs, with $\geq 550$ mosmol/l (Mantel \& Farmer, 1983), maintain a rather high osmotic concentration in their body fluids, when compared to the above-mentioned "classical" freshwater animals with 200-400 mosmol/l. This aggravates the problem of passive salt losses via antennal gland and body surfaces, especially in freshwater. Therefore, the elucidation of such potent mechanisms in crab gills for salt uptake against this extremely steep osmotic gradient has been of prominent interest for invertebrate physiologists.

\section{ELECTROPHYSIOLOGICAL METHODS IN CRAB GILL INVESTIGATIONS}

A number of reports (for review, see Pequeux et al., 1988) deals with ion tracer flux measurements and biochemical assays which were performed to solve the question of how crab gills achieve their absorptive task, and how this depends on the ambient salinities. Various electrophysiological techniques have been very successfully used in the past to uncover and characterize ion transport processes in symmetrical and epithelial cells. However, to date, the only electrophysiological technique which has been routinely applied to isolated and perfused gills of different crab species is the measurement of the transbranchial potential difference (PD) (Smith \& Linton, 1971; Siebers et al., 1985; Drews \& Graszynski, 1987; Pequeux \& Gilles, 1988). In fact, under certain well-defined experimental conditions, the observation of this parameter can provide valuable information. Unfortunately, the interpretation of PD-data (without area-specific conductances; measured simultaneously) is rather limited, due, for instance, to their often complex dependence on cellular and paracellular circuit parameters and tissue geometry. 


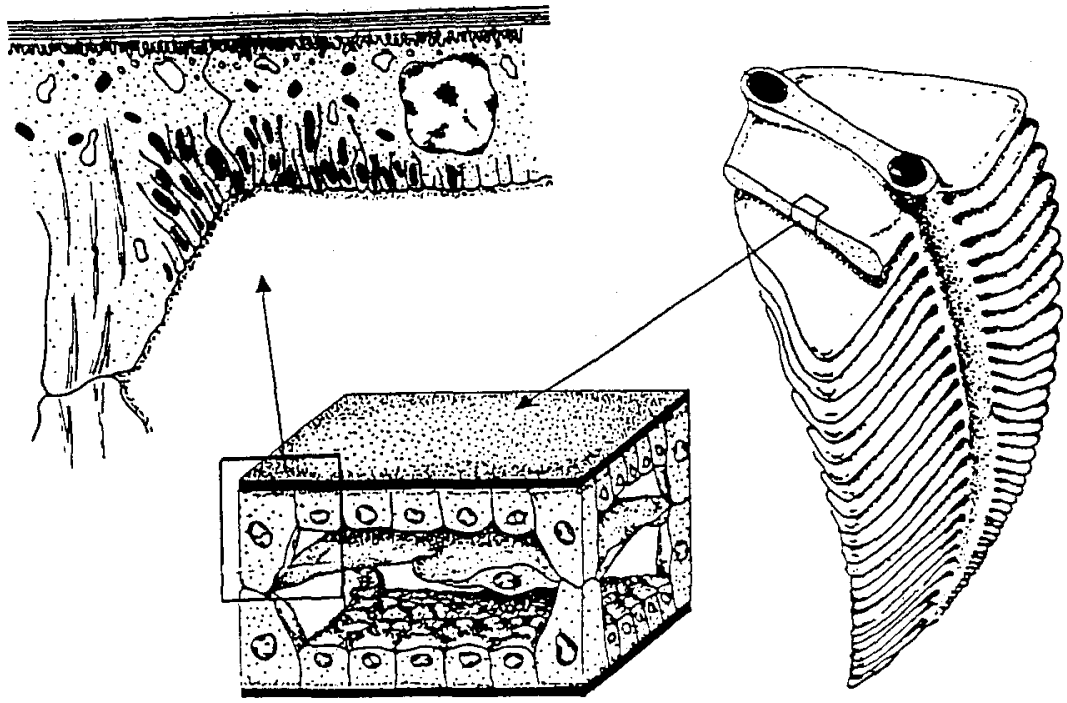

Fig. 1. Schematic representation of morphology and fine structure of crab gills. Modified after Graszynski \& Bigalke (1987)

Such disadvantages are simple to overcome, when an epithelium can be mounted and voltage-clamped in an Ussing-type chamber. Since its introduction in the early' 'fifties (Ussing \& Zerahn, 1951), this technique has yielded a wealth of data and allowed great insight into transport mechanisms of epithelial tissues. However, a flat epithelial preparation, which seems hardly obtainable from a rather complex structure like the crab gill (see Fig. 1), is an absolute requirement for the application of this method. Only a few years ago, Schwarz \& Graszynski (1989) succeeded in splitting isolated single gill lamellae of the Chinese crab (Eriocheir sinensis). The resulting preparation, consisting of a small, single layer of adherent cuticle and epithelium, could then simply be mounted in a small version of an Ussing-chamber.

Only by using this method has it become possible to define ion-specific and arearelated currents and conductances in great detail: (a) unlike the PD which is a qualitative measure, quantitative parameters were obtained (Schwarz \& Graszynski, 1989; Onken et al., 1991; Zeiske et al., 1992; Onken \& Siebers, 1992); (b) cell impalements with microelectrodes via the basolateral membrane allowed the investigation of membrane potentials and conductances (Onken et al., 1991), and (c) application of current-noise analysis resulted in the unambiguous demonstration of $\mathrm{Na}^{+}$-channels in the apical gill membrane of the Chinese crab (Zeiske et al., 1992).

Unfortunately, a disadvantage of split lamella preparations of crab gills is that tracer flux measurements will be difficult, if not impossible, due to the unavoidably small surface area of the isolated epithelium. Thus, electroneutral processes cannot be recorded, as is possible with whole gills and with preparations of vesicle membrane. Comparisons of data and conclusions from electrophysiology with those obtained by other methodical approaches therefore require care and reservation. Beyond this, the 
split lamella preparation offers decisive advantages for a detailed characterization of the mechanisms involved in electrogenic ion movements across crab gill membranes.

\section{Carcinus maenas: A model for crabs migrating to brackish water}

An example of a crab that migrates to brackish water is the shore crab C. maenas (Mantel \& Farmer, 1983). Even though only sparse knowledge, derived from a single study on split lamella preparations of the gills of this species, has been available up to now (Onken \& Siebers, 1992), the results are useful for the comparative aspect of this article. With haemolymph-like $\mathrm{NaCl}$-salines on both sides of split lamella preparations from shore crabs adapted to low-salt media, a transbranchial PD of about $7 \mathrm{mV}$ (inside negative) was measured, thus being very close to the findings for isolated gills (Siebers et al., 1985; Lucu, 1990). Short-circuiting of the PD resulted in a short-circuit current $\left(\mathrm{I}_{\mathrm{sc}}\right)$ of about $-240 \mu \mathrm{A} / \mathrm{cm}^{2}$. [The negative polarity of $I_{s c}$ reflects a net inward movement of negative or a net outward movement of positive ions.] The current depended on the presence of $\mathrm{Na}^{+}$a nd Cl${ }^{-}$and on a functioning $\mathrm{Na}^{+} / \mathrm{K}^{+}$-ATPase (see Fig. 2). $\mathrm{I}_{\mathrm{sc}}$ was not

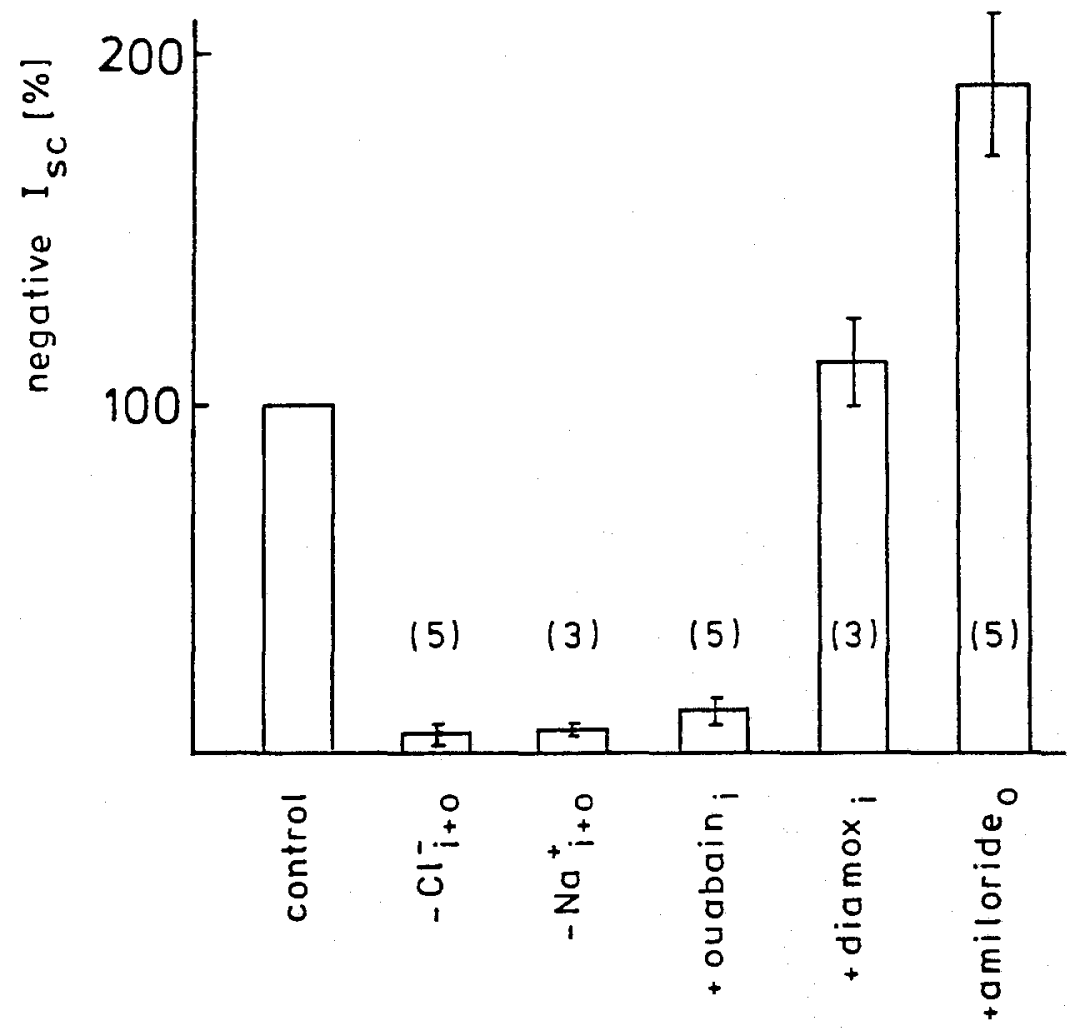

Fig. 2. Influence of ion substitutions and some external (o) and internal (i) inhibitors [2 mmol/l ouabain, $0.1 \mathrm{mmol} / \mathrm{l}$ diamox (acetazolamide), maximal (0.05-0.2 $\mathrm{mmol} / \mathrm{l})$ amiloride] on the negative short-circuit current $\left(\mathrm{I}_{\mathrm{sc}}\right)$ across split lamella preparations of posterior gills of low-salt adapted Carcinus maenas in $\%$ of the control $(=100 \%)$. Sample numbers in brackets. Vertical bars indicate standard error of the mean 
sensitive to acetazolamide, confirming former flux measurements (Böttcher et al., 1991), which already indicated that $\mathrm{NaCl}$-uptake across the gills of the shore crab is independent of the carbonic anhydrase and does not seem to proceed via electroneutral $\mathrm{Na}^{+} / \mathrm{H}^{+}$and $\mathrm{Cl}^{-} / \mathrm{HCO}_{3}{ }^{-}$-exchangers in the apical membrane. The conductance across cuticle and epithelium $\left(\mathrm{G}_{\mathrm{t}}\right)$, about $40 \mathrm{mS} / \mathrm{cm}^{2}$ under control conditions, only decreased after substitution of $\mathrm{Na}^{+}$but not $\mathrm{Cl}^{-}$, showing that the overall conductance of the tissue is dominated by sodium.

Another feature of the gill epithelium of the shore crab was its sensitivity to the epithelial $\mathrm{Na}^{+}$transport blocker, the diuretic amiloride (Benos, 1982). In a dose-dependent manner, the negative $I_{s c}$ became more negative and $G_{t}$ decreased with a halfmaximal concentration ( $\mathrm{K}_{\mathrm{AMI}}$ ) of about $10 \mu \mathrm{mol} / \mathrm{l}$ (Onken \& Siebers, 1992), which is in the currently reported range for apical $\mathrm{Na}^{+}$channels from invertebrate epithelia (Dannenmaier et al., 1991; Zeiske et al., 1992). These effects, consistent with the drug-induced inhibition of a positive $I_{s c}$ (probably the net inward movement of positive ions), may indicate the presence of an active and electrogenic $\mathrm{Na}^{+}$-uptake parallel to the mechanisms responsible for negative $\mathrm{I}_{\mathrm{sc}}$, which is likely to reflect electrogenic $\mathrm{Cl}^{-}$uptake. The apical site of interaction with the diuretic seems not to be (as was postulated by Shetlar \& Towle [1989]), an electrogenic $2 \mathrm{Na}^{+} / 1 \mathrm{H}^{+}$-exchanger: in their studies, using a preparation of mixed plasma membrane vesicles from Carcinus gills, $\mathrm{K}_{\mathrm{AMI}}$ was $280 \mu \mathrm{mol} / \mathrm{l}$, which is clearly many orders of magnitude greater than in the experiments on isolated epithelia but typical for other $\mathrm{Na}^{+} / \mathrm{H}^{+}$-exchangers (Benos, 1982). However, our suggestion of apical $\mathrm{Na}^{+}$channels (see Fig. 3) needs further support, e.g. by amiloride-induced currentnoise analysis (see below for Eriocheir).

The results obtained so far for the gills of the shore crab are compatible with a model where two cell types operate in parallel, one displaying co-transport-like $\mathrm{NaCl}$ uptake, similar to that in the thick, ascending limb of Henle's loop of the mammalian nephron (cf. Greger, 1985), and the other one with characteristics of amiloride-sensitive, channelmediated $\mathrm{Na}^{+}$uptake by frog skin (cf. Erlij \& Ussing, 1978). A similar model (see Fig. 3) has already been tentatively proposed for the gills of the fiddler crab Uca tangeri, which

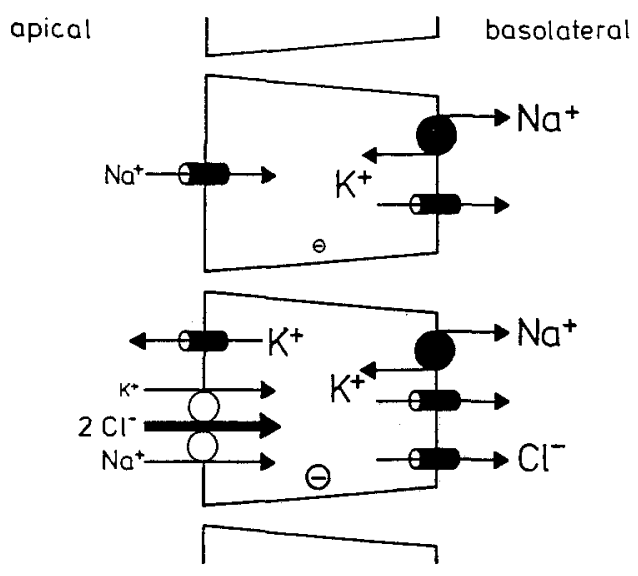

Fig. 3. Proposed functional model for $\mathrm{NaCl}$ uptake across posterior gills of low-salt adapted Carcinus maenas 
also migrates to brackish water (Drews, 1985; Graszynski \& Bigalke, 1987). While the mechanisms implicit in transport across the basolateral membrane have been fairly well demonstrated for the shore crab (Lucu \& Siebers, 1987; Siebers et al., 1990), there is no clear evidence of the mechanisms involved in the apical transport modes for $\mathrm{Na}^{+}$and $\mathrm{Cl}^{-}$ in either UCa tangeri or Carcinus maenas. However, the model for ion transport across gills of crabs migrating to brackish water proposed in Figure 3 may serve as a good basis for more detailed investigations in the future.

\section{Eriocheir sinensis: A model for crabs which conquered freshwater}

Only tropic and subtropic species of the Potamonidae and some Grapsidae, living in small water accumulations between the leaves of bromelia in tropical rain forests, have become completely independent of seawater due to an ontogenetic development similar to that in crayfish (elimination of planktonic stages). Unfortunately, little is known about osmoregulation in these species (Mantel \& Farmer, 1983), which are hardly obtainable for laboratory use. However, the Chinese crab Eriocheir sinensis may serve as a good substitute. This species passes through some planktonic stages in seawater before it migrates upstream in Central European and East Asian rivers. After spending an essential part of its lifetime in freshwater, the now-adult Chinese crab returns to the sea to reproduce.

In the past few years, most information has been gathered using the above described electrophysiological techniques on isolated epithelia of the posterior gills of Chinese crabs acclimated to freshwater. In the following, we focus on basic data and those results which are important to understand the proposed transport model shown in Figure 4. More detailed information, like kinetics or regulation of $\mathrm{NaCl}$ uptake, can be found elsewhere (Onken, 1989; Schwarz, 1990; Onken et al., 1991; Riestenpatt et al., 1992; Zeiske et al, 1992).

With haemolymph-like $\mathrm{NaCl}$-saline on both sides of split lamella prepartions of the Chinese crab, a PD of about $22 \mathrm{mV}$ (inside negative) was measured. Short-circuiting of

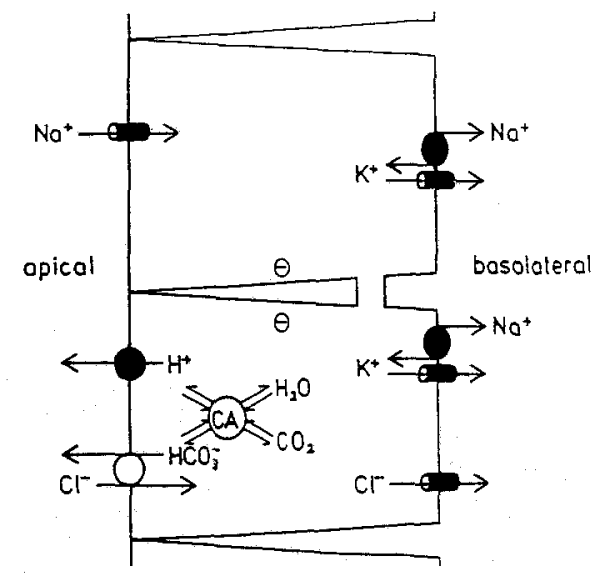

Fig. 4. Proposed funcitonal model for $\mathrm{NaCl}$ uptake across posterior gills of Eriocheir sinensis acclimated to freshwater 


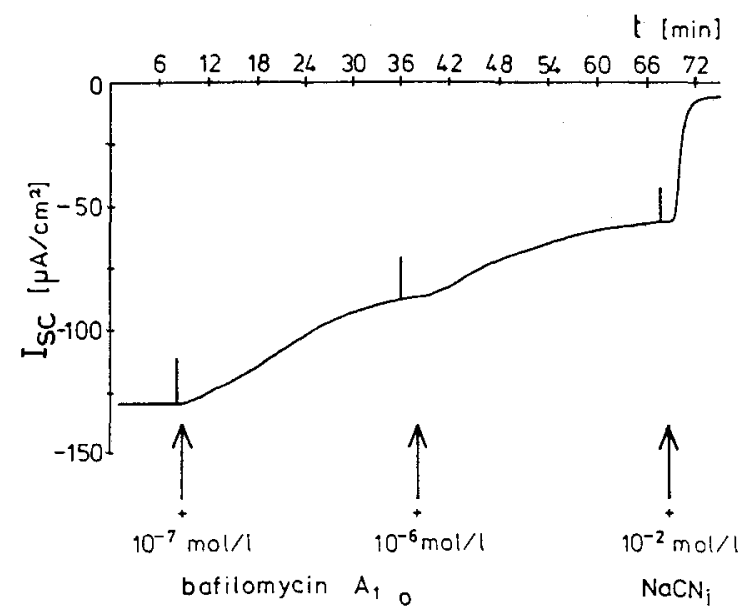

Fig. 5. Effect of external (o) bafilomycin $\mathrm{A}_{1}$ and internal (i) $\mathrm{NaCN}$ on negative $\mathrm{I}_{\mathrm{sc}}$ across a split lamella preparation of Eriocheir sinensis acclimated to freshwater. The vertical bars are due to constant voltage pulses and are proportional to $\mathrm{G}_{\mathrm{t}}$

this voltage resulted in a negative $I_{\mathrm{sc}}$ of about $-64 \mu \mathrm{A} / \mathrm{cm}^{2} . \mathrm{G}_{\mathrm{t}}$ amounted to about $3 \mathrm{mS}$ / $\mathrm{cm}^{2}$ under these conditions (Onken et al., 1991). The negative current, which even became more negative after external substitution of $\mathrm{Na}^{+}$(choline), depended on the presence of $\mathrm{Cl}^{-}$in the external bath and obviously represented a $\mathrm{Na}^{+}$-independent, electrogenic $\mathrm{Cl}^{-}$uptake. Our working model for this $\mathrm{Cl}^{-}$transport is shown in Figure 4 (lower cell type): apically involved are a $\mathrm{H}^{+}$-ATPase parallel to a $\mathrm{Cl}^{-} / \mathrm{HCO}_{3}{ }^{-}$-exchanger, both "powered" by carbonic anhydrase-catalyzed $\mathrm{CO}_{2}$-hydrolysis. Basally involved are $\mathrm{Cl}^{-}$and $\mathrm{K}^{+}$channels. The " $\mathrm{Cl}^{-}$current" could be inhibited with external 4 -acetamido-4' isothiocyanato-stilbene-2,2' - disulfonic acid (SITS, inhibitor of $\mathrm{Cl}^{-} / \mathrm{HCO}_{3}$-exchange) or with external bafilomycin $\mathrm{A}_{1}$ (see Fig. 5), a specific inhibitor of vacuolar type $\mathrm{H}^{+}$-ATPases (Wieczorek et al., 1991). Equally effective were internal diphenylamine-2-carboxylate (DPC, inhibitor of $\mathrm{Cl}^{-}$-channels) or acetazolamide (inhibitor of the carbonic anhydrase). However, internal ouabain, the well-known inhibitor of the $\mathrm{Na}^{+} / \mathrm{K}^{+}$-ATPase did not reduce $\mathrm{Cl}^{-}$current (Onken et al., 1991).

The driving force for secondary active $\mathrm{Cl}^{-}$uptake via apical $\mathrm{Cl}^{-} / \mathrm{HCO}_{3}{ }^{-}$-exchange is provided by the cooperation of carbonic anhydrase and the $\mathrm{H}^{+}$-ATPase, of which the latter is also clearly the candidate for the transapical electrical current pathway. Although not directly dependent on a functioning $\mathrm{Na}^{+} / \mathrm{K}^{+}$-ATPase (see above), this ion pump should stimulate $\mathrm{Cl}^{-}$uptake by its indirect influence on the cellular electrical potential (via generation and conservation of a $\left[\mathrm{K}^{+}\right]$-gradient across the basolateral membrane). The basolateral passive $\mathrm{Cl}^{-}$exit via DPC-sensitive channels depends on the negative cell potential which is partly generated by the $\mathrm{H}^{+}$-ATPase, and partly reflects the basolateral $\mathrm{K}^{+}$-dependent membrane voltage. This is indicated by the sensitivity of negative $\mathrm{I}_{\mathrm{sc}}$ to bafilomycin (see Fig.5) and of the cellular potential to high haemolymph-side $\mathrm{K}^{+}$ concentrations (Onken et al., 1991).

A completely different feature of the gills of the Chinese crab appeared, when working with $\mathrm{Cl}^{-}$-free saline in the external bath. Under these conditions, the polarity of 


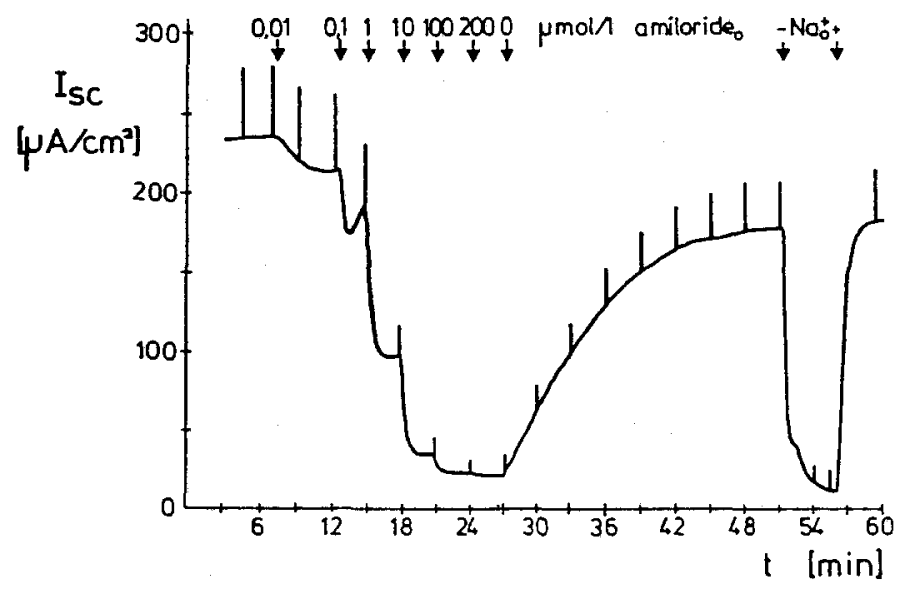

Fig. 6. Time-course of the positive short-circuit current across a split lamella preparation of Eriocheir sinensis acclimated to freshwater with $\mathrm{Cl}^{-}$-free saline in the external and haemolymph-like $\mathrm{NaCl}$ saline in the internal bath, showing the influence of different external (o) amiloride concentrations and external (o) substitution of $\mathrm{Na}^{+}$(Trisgluconate-saline). The vertical bars are due to constant voltage pulses and are proportional to $G_{t}$

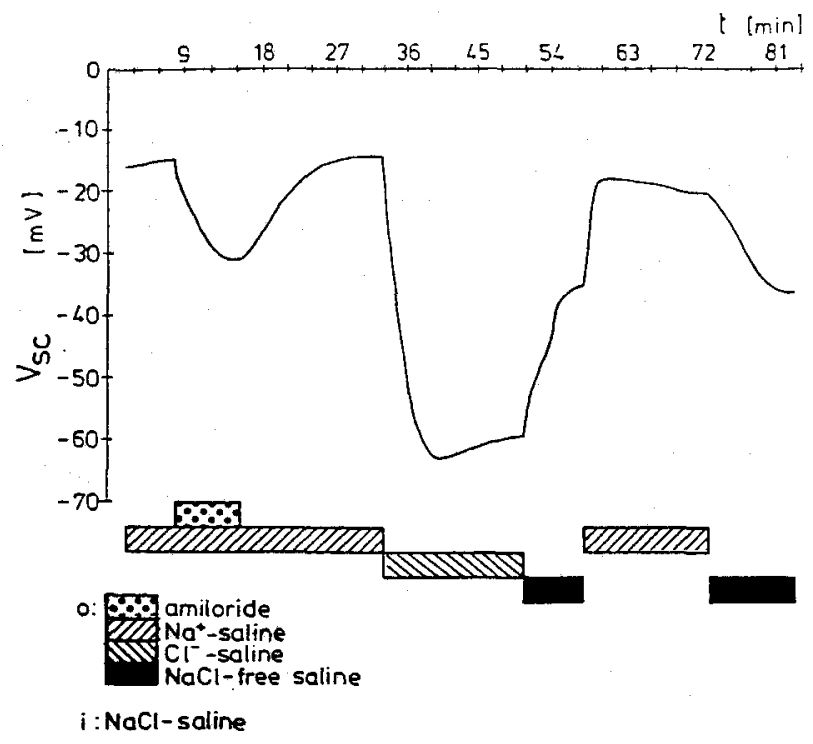

Fig. 7. Time-course of the cellular potential $\left(\mathrm{V}_{\mathrm{sc}}\right)$ after impaling a cell of a short-circuited split lamella preparation of Eriocheir sinensis acclimated to freshwater. The signal is related to either $\mathrm{Na}^{+}$uptake (external $\mathrm{Na}^{+}$-saline), or $\mathrm{Cl}^{-}$uptake (external $\mathrm{Cl}^{-}$-saline), or non-transporting conditions (external $\mathrm{Na}^{+}$-saline pius $0.2 \mathrm{mmol} / \mathrm{l}$ amiloride or $\mathrm{NaCl}$-free saline). Internal haemolymph-like $\mathrm{NaCl}$-saline, during the whole period 
$\mathrm{I}_{\mathrm{sc}}$ reversed. This positive $\mathrm{I}_{\mathrm{sc}}$ depended on external $\mathrm{Na}^{+}$and was highly sensitive (halfmaximal effect below $1 \mu \mathrm{mol} / \mathrm{l}$ ) to external amiloride (Schwarz, 1990; Zeiske et al., 1992; see Fig. 6, this paper) as well as to internal ouabain (Schwarz, 1990). The positive $I_{\mathrm{sc}}$ represents active $\mathrm{Na}^{+}$uptake via apical $\mathrm{Na}^{+}$-channels, as was unambiguously shown by the analysis of amiloride-induced current-noise (Zeiske et al., 1992).

With respect to the intraepithelial localization of the mechanisms discussed for $\mathrm{Cl}^{-}$ and $\mathrm{Na}^{+}$uptake (see Fig. 4), an interesting result was obtained by immunofluorescent representation of a gill $\mathrm{H}^{+}$-ATPase (Putzenlechner et al., 1992) with monoclonal antibodies against the $\mathrm{V}$-type apical $\mathrm{H}^{+}$-ATPase from caterpillar midgut (Klein et al., 1991; Wieczorek et al., 1991). Immunostaining was only seen in the so-called pilaster cells, formerly assumed to stabilize only the haemolymph space between the two epithelial layers inside a gill lamella (see Fig. 1). On the other hand, microelectrode experiments (see Fig. 7) reflect all possible transport states after impaling a single cell. In the absence of any transport ( $\mathrm{Na}^{+}$-saline with amiloride or $\mathrm{NaCl}$-free saline), the cellular potential at short-circuit is in the range of -30 to $-40 \mathrm{mV}$. With $\mathrm{Na}^{+}$uptake $\left(\mathrm{Na}^{+}\right.$-saline), the cellular potential de-polarises, but it hyper-polarises with $\mathrm{Cl}^{-}$-uptake $\left(\mathrm{Cl}^{-}\right.$-saline). These results indicate that all mechanisms will contribute to the signal sensed by the microelectrode. Thus, unlike in the model proposed for the shore crab (see Fig.3), all cells in the gill epithelium of Eriocheir seem to be at least electrically coupled (as suggested in Fig. 4), and independent modes of electrogenic $\mathrm{Na}^{+}$and $\mathrm{Cl}^{-}$uptake are consequently alternative and/or complementary instruments of the tissue for osmoregulation.

\section{CONCLUSION AND COMPARATIVE REMARKS}

Gill epithelia from crabs which were acclimated to diluted media show the same polarity of PD (inside negative) and $\mathrm{I}_{\mathrm{sc}}$ (inward negative) with haemolymph-like $\mathrm{NaCl}$ salines on both sides, when the voltage-clamped split lamella preparation is investigated in an Ussing-chamber. However, the magnitudes of these parameters, and in particular $P D$ and $G_{t}$ already differ significantly. While the gills of the shore crab (representative of crabs migrating to brackish water) are "leaky", the gills of the Chinese crab (representative of crabs migrating to freshwater) are moderately "tight". With respect to the suggested mechanisms involved in transbranchial $\mathrm{NaCl}$ uptake, the gills of the shore crab show similarities to other salt-absorbing, "leaky" epithelia exposed to moderately diluted media. The gills of the Chinese crab, on the other hand, show striking similarities to the co-operating mitochondria-rich and principal cells, which both seem to mediate $\mathrm{NaCl}$ uptake across frog skin under in vivo conditions (Harvey \& Ehrenfeld, 1988; Larsen, 1988).

Acknowledgement. We gratefully acknowledge the continuous financial support of our work by the Deutsche Forschungsgemeinschaft.

\section{LITERATURE CITED}

Benos, D. J., 1982. Amiloride: a molecular probe of sodium transport in tissues and cells. - Am. J. Physiol. 242, C131-145.

Böttcher, K., Siebers, D., Becker, W. \& Petrausch, G., 1991. Physiological role of branchial carbonic anhydrase in the shore crab Carcinus maenas. - Mar. Biol. 110, 337-342. 
Dannenmaier, B., Heinke, B., Weber, W. M. \& Clauss, W., 1991. Amiloride-sensitive Na+-channels in the dorsal skin of Hirudo medicinalis. - Verh. dt. zool. Ges. 84, 402-403.

Drews, G., 1985. Elektrophysiologische und biochemische Untersuchungen zur osmoregulatorischen Fähigkeit und zur Salzaufnahme über das Kiemenepithel von Uca tangeri (Eydoux, 1835). Diss., F. U. Berlin, 139 pp.

Drews, G. \& Graszynski, K., 1987. The transepithelial potential difference in the gills of the fiddler crab, Uca tangeri: influence of some inhibitors. - J. comp. Physiol. 157, 345-353.

Erlij, D. \& Ussing, H. H., 1978. Transport across amphibian skin. In: Membrane transport in biology. Ed. by G. Giebisch, D. C. Tosteson \& H. H. Ussing. Springer, Berlin 3, 178-208.

Graszynski, K. \& Bigalke, T., 1987. Osmoregulation and ion transport in the extremely euryhaline fiddler crabs Uca pugilator and Uca tangeri (Ocypodidae). - Zool. Beitr. 30, 339-358.

Greger, R., 1985. Ion transport in thick ascending limb of Henle's loop of mammalian nephron. Physiol. Rev. 65, 760-797.

Harvey, B. J. \& Ehrenfeld, J., 1988. Epithelial pH and ion transport by proton pumps and exchangers. - Ciba Fdn Symp. 139, 139-164.

Klein, U., Löfelmann, G. \& Wieczorek, H., 1991. The midgut as a model system for insect $\mathrm{K}^{+}$transporting epithelia: immunocytochemical localization of a vacuolar-type $\mathrm{H}^{+}$pump. $-\mathrm{J}$. exp. Biol. 161, 61-75.

Larsen, E. H., 1988. NaCl transport in amphibian skin. - Adv. comp. environ. Physiol. 1, $189-248$.

Lucu, ¿́., 1990. Ionic regulatory mechanisms in crustacean gill epithelia. - Comp. Biochem. Physiol. 97A, 297-306.

Lucu, C. \& Siebers, D., 1987. Linkage of $\mathrm{Cl}^{-}$fluxes with ouabain sensitive $\mathrm{Na} / \mathrm{K}$ exchange through Carcinus gill epithelia. - Comp. Biochem. Physiol. 87. 807-811.

Mantel, L. H. \& Farmer, L. H., 1983. Osmotic and ionic regulation. In: The biology of crustacea. Ed. by D. E. Bliss. Acad. Press, New York 5, 53-161.

Onken, H., 1989. Elektrophysiologische Untersuchung zur transepithelialen $\mathrm{Cl}^{-}$-Aufnahme über die posterioren Kiemen der Wollhandkrabbe Eriocheir sinensis: Von der Untersuchung ganzer Kiemen zur Zellpunktion. Diss., F.U. Berlin, $174 \mathrm{pp}$.

Onken, H. \& Siebers, D., 1992, Voltage-clamp measurements on single split lamellae of posterior gills of the shore crab Carcinus maenas. - Mar. Biol. 114, 385-390.

Onken, H., Graszynski, K. \& Zeiske, W., 1991. Na ${ }^{+}$-independent, electrogenic $\mathrm{Cl}^{-}$uptake across the posterior gills of the Chinese crab (Eriocheir sinensis): voltage-clamp and microeletrode studies. - J. comp. Physiol. 161, 293-301.

Pequeux, A. \& Gilles, R., 1988. The transepithelial potential difference of isolated perfused gills of Chinese crab Eriocheir sinensis acclimated to fresh water. - Comp. Biochem. Physiol. 89A, 163-172.

Pequeux, A., Gilles, R. \& Marshall, W. S., 1988. NaCl transport in gills and related structures. - Adv. comp. environ. Physiol. 1, 1-73.

Putzenlechner, M., Onken, H., Klein, U. \& Graszynski, K., 1992. Electrogenic $\mathrm{Cl}^{-}$-uptake across the gill epithelium of Eriocheir sinensis: energized by a V-type proton-ATPase? - Verh, dt. zool. Ges. 85 (1), 160 .

Riestenpatt, S., Onken, H. \& Graszynski, K., 1992. The stimulation of electrogenic $\mathrm{Na}^{+}$and $\mathrm{Cl}^{-}$ uptake across the epithelium of posterior gills of Eriocheir sinensis by theophylline. - Verh. dt. zool. Ges. 85 (1), 161.

Schwarz, H.-J,, 1990. Elektrophysiologische Untersuchungen des transepithelialen Natrium-Transportes isolierter, halbierter Kiemenplättchen posteriorer Kiemen der Wollhandkrabbe Eriocheir sinensis und der Winkerkrabbe Uca tangeri. Diss., F.U. Berlin, $136 \mathrm{pp}$.

Schwarz, H.-J. \& Graszynski, K., 1989. Ion transport in crab gills: a new method using isolated half platelets of Eriocheir gills in an Ussing-type chamber. - Comp. Biochem. Physiol. 92A, 601-604.

Shetlar, R. E. \& Towle, D. W., 1989. Electrogenic sodium-proton exchange in membrane vesicles from crab (Carcinus maenas) gill. - Am. J. Physiol. 257, R924-R931.

Siebers, D., Winkler, A., Lucu, C., Thedens, G. \& Weichart, D., 1985. Na-K-ATPase generates an active transport potential in the gills of the hyperregulating shore crab Carcinus maenas. - Mar. Biol. 87, 185-192.

Siebers, D., Lucu, C. \& Winkler, A., 1987. Active influx of ions across gills of osmoregulating shore crabs Carcinus maenas. - Zool. Beitr. 30, 315-338. 
Siebers, D., Böttcher, K., Petrausch, G. \& Hamann, A., 1990. Effects of some chloride channel blockers on potential differences and ion fluxes in isolated perfused gills of shore crabs Carcinus maenas. - Comp. Biochem. Physiol. 97A, 9-15.

Smith, D. S. \& Linton, J. R., 1971. Potentiometric evidence for the active transport of sodium and chloride across excised gills of Callinectes sapidus. - Comp. Biochem. Physiol. 39A, 367-378.

Ussing, H. H. \& Zerahn, K., 1951. Active transport of sodium as the source of electric current in the short-circuited isolated frog skin. - Acta physiol. scand. 23, 110-127.

Wieczorek, H., Putzenlechner, M., Zeiske, W. \& Klein, U., 1991. A vacuolar-type proton pump energizes $\mathrm{K}^{+} / \mathrm{H}^{+}$antiport in an animal plasma membrane. - J. biol. Chem. 266, 15340-15347.

Zeiske, W., Onken, H., Schwarz, H.-J. \& Graszynski, K., 1992. Invertebrate epithelial Na ${ }^{+}$channels: amiloride-induced current॰noise in crab gill. - Biochim. biophys. Acta 1105, 245-252. 